\title{
FACTOR RELATIONS IN AGRICULTURE - CONCEPTUAL REASONING WITH EMPIRICAL VERIFICATION
}

\author{
AGNIESZKA BEZAT-JARZĘBOWSKA
}

\begin{abstract}
The research presented in the paper allowed the author not only to fully recognize the correctness of production processes, but also determine the relations between production factors and production volumes (productivity and factor relations). Based on the adopted analytical assumptions and general conditions of farming processes in agriculture, the paper analyzes relations between production factors, i.e., the essence of production techniques. The research on relations between production factors is very complex, thus the paper focuses only on some areas of the issue, such as: labor productivity and its dependency on technical equipment of labor or agrarian structure (approximate land-labor ratio) and the dependency of capital-labor and land-labor ratios on production factors. The analysis is based on the principle of generality and the methodological approach for deduction is used in the paper. The empirical part of the paper uses the dataset for selected EU countries. It was concluded that the $\left(\frac{K}{L}\right)$ ratio, relatively to $\left(\frac{Z}{L}\right)$ ratio, has a greater impact on the level of labor productivity. These conclusions may be significant for agricultural policy, since improving the agrarian structure does not seem to be a priority, whereas the technical equipment of labor seems to be more important. Thus, it is crucial to increase the involvement of the capital factor.
\end{abstract}

Keywords: factor relations, agricultural productivity, production factors.

JEL codes: O13, D24, C23. 


\section{Introduction}

Agricultural sector plays an important role in shaping economic growth. The concept is strongly grouned in the theory of economics (e.g., Hayami and Ruttan, 1985; Woś and Tomczak, 1983). The specific role of agricultural sector is connected to the productivity of production factors. Some authors claim that higher productivity of production factors in agriculture accelerates economic growth (Jorgenson, 1961; Ranis and Fei, 1961). In the literature, changes in productivity in agriculture were analyzed as a factor determining growth in the industrial sector. The positive relationship between productivity in agriculture and the development of the industrial sector was demonstrated by K.M. Murphy, A. Shleifer and R. Vishny (1989).

Y. Hayami and V. Ruttan (1970) addressed this issue by stating that changes in the proportion of production factors illustrate the process of dynamic substitution caused by relative changes in the prices of these factors. The price of production factors results from the proportion of their scarcity, i.e., from the market price of the given factor specified by the supply and demand relationships of the factor concerned. Technical progress, human capital, knowledge, and all qualitative characteristics also fall within the factor relationship (Rembisz and Waszkowski, 2017).

In the economy, changes in the relative prices of production factors follow the general development. It is influenced by technological changes causing a fall in the relative prices of capital, technological progress itself, including widespread digitization, mobility, etc. There is a race between technology, the modern factor of capital, and the labor factor, education and skills (human capital). The farmer model is also different today due to physical work being replaced by organizational work, developing competencies related to new technologies and biological progress, as well as the knowledge of business, economics, and finance. All these aspects change the assessment of the rationality of certain relations among production factors. This causes ever deeper changes in production techniques, also in agricultural production. The production technique is a clear and relatively easy category, sometimes seemingly, for empirical identification. In the world literature, this issue was explored mainly by Ruttan who put forward an idea about determining the characteristics and types of agricultural development. The issue was also examined in the paper by Harlemann-Stamer (1963) and the growth models of Kuznets.

In terms of production factors, the significance of factor relationships for the management process and growth was first studied by the great economist J.B. Say. He proved that factor relationships influence the efficiency of the production process and attributed the same role to them, in creating value, without distinguishing labor as an active factor, as well as capital and land as passive factors (Bezat-Jarzębowska and Rembisz, 2018). Nevertheless, he claimed that the labor factor uses the forces of nature - the land factor and the accumulated labor of previous generations as a factor of capital (in financial and material terms). This concept was further developed by J.B. Clark (Clark, 1915). It is emphasized that the concept of production factors is the most abstract approach to the material elements of the production process 
used to analyze the correctness of the production and growth process, which is of general and universal nature and theoretical dimension. Theoretical in the sense that factor relationships are the basis for explaining what is perceived as the effect of the production process.

The analytical support in the discussed area is a universal cognitive construct describing economic and production processes in agriculture, i.e., a production function illustrating available and effectively used manufacturing techniques. It is pointed out that the three-factor analysis is a distinctive feature that distinguishes agricultural economics from other areas of economics. The production function is presented as a universal concept, describing economic and production processes in agriculture at the level of the producer and the sector. This applies in particular to the analysis of production efficiency, productivity of production factors and production techniques. It is assumed that the production function illustrates the available and effectively used production techniques, because it defines the volume $(y)$ of output (production) that can be generated at a given level of engagement of production factor $(s)$. In this sense, the production function reflects a given state of technology, including the technique, organization, knowledge, experience, progress, and innovation. The long-lasting traditions in this field are part of agricultural economics, starting with publications by Heady and Dillon (1961), Woś and Tomczak. The concept of production function is widely discussed in the literature (Shepard, 1953; Shepard, 1970; Aigner and Chu, 1968; Fried, Lovell and Schmidt, 2008).

As regards the nature of this function, the factor-product relations are of relevance, i.e., the relationship between production factors involved and the product obtained, which defines the efficiency of production (assuming a given technology) and is directly related to the purpose of the agricultural producer's function and, more broadly, to economic growth being its endogenous source. The productivity relations can be recognized as the ratio of revenues from production in constant prices (then, they depict the production value and approach the ideal, i.e., the amount quantified as the basis for technical efficiency) to the involvement of a given factor recognized as a resource or expenditure (in both cases expressed in constant prices). Determined productivity relations (the indicators of partial production efficiency, referred to as the productivity factors of individual production factors) include labor factor productivity, productivity of the capital factor, and productivity of the land factor. A common feature of the above coefficients is their endogenous nature. In the sense that the formation and level of these coefficients depend primarily on the agricultural producer, mainly on the absorption of general technical progress by the producer and the opportunities resulting from economic development. These partial productivities, when appropriately aggregated, are commonly referred to in the literature as the TFP coefficient (Total Factor Productivity), in which the production volume refers to the sum of the involved factors (resources).

Parallel to the factor-product relations, the factor-factor relations occur in the production processes, the assessment of which can provide a deeper insight into production techniques, as the relations of this type illustrate the proportions in 
which production factors are combined to achieve a given volume of production. The factor relation is a category referring to the relationship among the following production factors: labor, capital, and land. It can refer to production techniques, but also production efficiency, which is always and in all conditions related to the way of linking and using production factors. Certainly, this is the praxeological aspect of economics and refers to the production and economic or technical and economic areas of the management process, including growth. There are certain regularities and laws referring to the relationship between the effect and the factor of production and the factor relations themselves evaluated in terms of efficiency and effectiveness of using production factors in the management process. In fact, management is nothing else than just combining production factors in the production process, in terms of functioning and growth, based on the principle of rationality (maximizing the effect of a given involvement of factors or minimizing the involvement of these factors to achieve a given production effect). The essential role of mutual relations among the three production factors is expressed not only in their impact on the production result, but also on the economics of production.

The research on relations among production factors is very complex, thus the paper discusses some aspects of the issue. The paper addresses the following questions concerning the relations among the labor, capital, and land factors (the aspects of manufacturing techniques):

- Is labor productivity $\left(\frac{y}{L}\right)$ more dependent on the capital-labor ratio $\left(\frac{K}{L}\right)$ or the land-labor ratio $\left(\frac{Z}{L}\right)$ ?

- Is the capital-labor ratio shaped more by the loss of the labor factor or by the increased use of the capital factor?

- Is the land-labor ratio shaped more by the land factor or by the labor factor?

The logical relation between the research questions is shown in Figure 1.

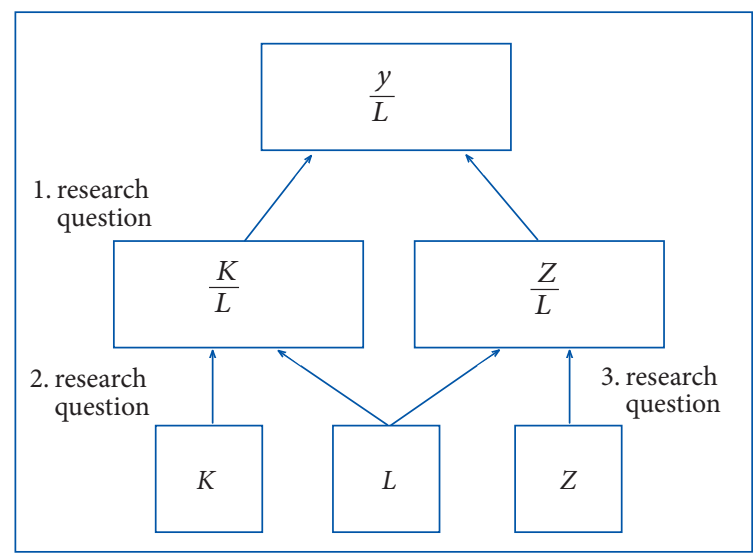

Fig. 1. Logical structure of research questions.

Source: own elaboration. 
The paper is divided into three sections. The Methods and Data section discusses algebraic relations and econometric models. It also describes data sources and database. The Results section assesses the coefficients of econometrics models and discusses the obtained relations, thus verifies the questions raised. Finally, the concluding remarks are presented in the last section.

\section{Methods and Data}

In the paper, the neoclassical reasoning is used. The analysis is based on the principle of generality and the methodological approach for deduction is used. The approach to the relationship of agricultural production factors is presented on a sector scale. Based on the adopted analytical assumptions and general conditions of farming processes in agriculture, the relationships between production factors, i.e., the essence of production techniques, are analyzed. The resulting analytical reasoning and conclusions are the basis for specifying econometrical models and further empirical verification.

In the theory of economics, factor relationships are a matter of allocation and the producer's choice. Another issue is the regulatory or market mechanism or one related to policy (e.g., economic and agricultural, legal, etc.) and its instruments affecting this allocation and choices made by producers. However, given constraints or institutional and legal stimuli and specific policy and assuming the maximization of the goal function of the producer, this regulatory mechanism, especially the market, leads to specific choices regarding relationships between production factors used to obtain specific output.

The goal function of the agricultural producer is maximizing the difference between revenue and costs, thus maximizing the profit, which is expressed by the following formula:

$$
\left\{y \cdot p_{y}-\left(K \cdot p_{K}+L \cdot p_{L}+Z \cdot p_{Z}\right)\right\} \max _{y}
$$

where:

$y$ - agricultural production,

$p_{y}$ - price of agricultural products,

$L, K, Z$ - labor, capital, and land factors,

$p_{L}, p_{K}, p_{Z}-$ remuneration for production factors or prices of these factors.

In the above general formula, the variables that depend on the agricultural producer include: $\{y, K, L, Z\}$ and, above all, their mutual relations of two types.

The fist type is the relation of production (product) to a given factor, i.e., its productivity. According to three factors of production, one can distinguish:

$$
\frac{y}{L} ; \frac{y}{K} ; \frac{y}{Z}
$$


The second type is the relations between the production factors themselves, which characterize production techniques in agriculture understood as a set of producers. Among various combinations of the factor relations (the relations between production factors), the following three groups of relations seem to be the most important, according to the tradition of agricultural economics:

$$
\frac{K}{L} ; \frac{Z}{L} ; \frac{K}{Z}
$$

Firstly, $\frac{K}{L}$ is the most fundamental and the best known relation called differently in economics usually technical equipment of labor. It characterizes the intensity of using this factor. This illustrates the degree of innovation (if more and more modern technology is embodied in the capital factor) and mechanization, which determines the efficiency of the labor factor, but also indirectly the productivity of the capital factor.

Secondly, $\frac{Z}{L}$ is the relation between the land factor and the labor factor is specific and critical for agriculture in terms of the determinant of productivity of the labor factor, and hence income. It indicates the type of agriculture and its most important characteristics, i.e., agrarian structure and the degree of concentration (its high values are agricultural holdings with large area). Nevertheless, increasing the ratio without increasing productivity of the land factor is not a very rational process, it is characterized by extensive growth. As it is known, this is a specific feature of agriculture when it comes to conditions that shape the efficiency of the labor factor and all socio-cultural and political aspects.

Thirdly, the $\frac{K}{Z}$, relation, thus the involvement of the capital factor to the land factor. This relation has a long tradition in the theory of agricultural intensification and refers to the intensity of using the land factor. High value of this coefficient is characteristic of industrial agriculture and serves as a basis or condition for high productivity of the land factor, and thus, in general high efficiency of the labor factor along with high income, e.g., at the parity level. In fact, this relation, affecting the productivity of the land factor, somehow limited (factor in the minimum), determines the level and increase of production and the productivity of other factors, and thus the efficiency of production at the current stage of development, therefore is a stimulant regardless of the assessment of the type of industrial agriculture (high level of this relation does not necessarily mean negative environmental effects). This relation is usually burdened with substitutive functions in relation to the loss or lack of growth of the land factor, but also indirectly in relation to the loss of the labor factor, and naturally investment is required to increase it.

In the further parts of the paper, these factor relations characteristic of the most important aspects of the production techniques, especially considering the identified types of growth in agriculture, are taken into consideration. Regarding these factorfactor relations as a base of consideration, some aspects of agricultural development are investigated. 
In order to answer the research questions, basic functional forms are investigated, thus linear, power, exponential, and logarithmic models are assessed.

In the case of the first research question, i.e., the dependency of labor productivity on the capital-labor ratio and the land-labor ratio, the following models are specified:

- linear model:

$$
\left(\frac{y}{L}\right)_{t}=\beta_{1} \frac{K_{t}}{L_{t}}+\beta_{2} \frac{Z_{t}}{L_{t}}+\varepsilon_{t}
$$

- power model:

$$
\left(\frac{y}{L}\right)_{t}=\left(\frac{K_{t}}{L_{t}}\right)^{\beta_{1}}\left(\frac{Z_{t}}{L_{t}}\right)^{\beta_{2}} \varepsilon_{t}
$$

in linearized form

$$
\ln \left(\frac{y}{L}\right)_{t}=\beta_{1} \ln \frac{K_{t}}{L_{t}}+\beta_{2} \ln \frac{Z_{t}}{L_{t}}+\ln \varepsilon_{t}
$$

- exponential model:

$$
\left(\frac{y}{L}\right)_{t}=e^{\beta_{1} \frac{K t}{L_{t}}+\beta_{2} \frac{Z_{t}}{L_{t}}+\varepsilon_{t}} .
$$

in linearized form

$$
\ln \left(\frac{y}{L}\right)_{t}=\beta_{1} \frac{K_{t}}{L_{t}}+\beta_{2} \frac{Z_{t}}{L_{t}}+\varepsilon_{t}
$$

- logarithmic model:

$$
\left(\frac{y}{L}\right)_{t}=\beta_{1} \ln \frac{K_{t}}{L_{t}}+\beta_{2} \ln \frac{Z_{t}}{L_{t}}+\varepsilon_{t}
$$

With regard to the second research question, the technical equipment of labor $\left(\frac{K}{L}\right)$ and its relation to the capital and labor factors are examined. To verify the question, the following models are specified:

- linear model:

$$
\left(\frac{K}{L}\right)_{t}=\beta_{1} K_{t}+\beta_{2} L_{t}+\varepsilon_{t}
$$

- power model:

$$
\left(\frac{K}{L}\right)_{t}=K_{t}^{\beta_{1}} L_{t}^{\beta_{2}} \varepsilon_{t}
$$

in linearized form

$$
\ln \left(\frac{K}{L}\right)_{t}=\beta_{1} \ln K_{t}+\beta_{2} \ln L_{t}+\ln \varepsilon_{t}
$$

- exponential model:

$$
\left(\frac{K}{L}\right)_{t}=e^{\beta_{1} K_{t}+\beta_{2} L_{t}+\varepsilon_{t}}
$$

in linearized form

$$
\ln \left(\frac{K}{L}\right)_{t}=\beta_{1} K_{t}+\beta_{2} L_{t}+\varepsilon_{t}
$$

- logarithmic model:

$$
\left(\frac{K}{L}\right)_{t}=\beta_{1} \ln K_{t}+\beta_{2} \ln L_{t}+\varepsilon_{t}
$$


In terms of the third research question, i.e., the dependency of the land-labor ratio on the land and labor factors, the following models are specified:

- linear model:

- power model:

$$
\left(\frac{Z}{L}\right)_{t}=\beta_{1} Z_{t}+\beta_{2} L_{t}+\varepsilon_{t}
$$

$$
\left(\frac{Z}{L}\right)_{t}=Z_{t}^{\beta_{1}} L_{t}^{\beta_{2}} \varepsilon_{t}
$$

in linearized form

$$
\ln \left(\frac{Z}{L}\right)_{t}=\beta_{1} \ln Z_{t}+\beta_{2} \ln L_{t}+\ln \varepsilon_{t}
$$

- exponential model:

$$
\left(\frac{Z}{L}\right)_{t}=e^{\beta_{1} Z_{t}} \cdot e^{\beta_{2} L_{t}} \cdot e^{\varepsilon_{t}}
$$

in linearized form

$$
\ln \left(\frac{Z}{L}\right)_{t}=\beta_{1} Z_{t}+\beta_{2} L_{t}+\varepsilon_{t}
$$

- logarithmic model:

$$
\left(\frac{Z}{L}\right)_{t}=\beta_{1} \ln Z_{t}+\beta_{2} \ln L_{t}+\varepsilon_{t}
$$

The coefficients of the models are assessed by using the least squared method. The results are presented at a given level of significance.

In the empirical part of the paper, the dataset for selected EU countries for 2005-2018 is used. The data comes from public Eurostat website which allows for the replicability of the study. The choice of countries for analysis was arbitrary, with the main premise being the availability of data throughout the study period.

\section{Results $^{1}$}

The first research question is whether labor productivity is more dependent on the capital-labor ratio or the land-labor ratio. This is related to well-known development dilemmas, e.g., from the Hayami-Ruttan model. The hypothetical assumption is that labor productivity changes in the same direction as the capital-labor ratio or the land-labor ratio. Thus, positive values of coefficients are expected. In the Table 1, the results of model estimation are presented (for each country the model with the highest R-squared ${ }^{2}$ ). The justification for the choice of the analytical form of the models used for the research is based on the R-squared assessment.

\footnotetext{
${ }^{1}$ The results focus on general changes in agricultural productivity. Referring to the distinctive features of agriculture in individual countries was beyond the scope of the research.

${ }^{2} \mathrm{R}$-squares are obviously high because the variables are correlated over time.
} 
Table 1

Estimated parameters and errors of regression models describing relation between the labor factor productivity and the $\frac{K}{L}$ and $\frac{Z}{L}$ ratios in the analyzed countries (at a significance level of 0.1)

\begin{tabular}{|c|c|c|c|c|c|c|}
\hline Country & R-squared & $\begin{array}{l}\text { Name of } \\
\text { coefficient }\end{array}$ & $\begin{array}{l}\text { Value of } \\
\text { coefficient }\end{array}$ & $\begin{array}{l}\text { Standard } \\
\text { error }\end{array}$ & $\mathrm{p}$-value & $\begin{array}{l}\text { Statistical } \\
\text { significance }\end{array}$ \\
\hline \multirow{2}{*}{ Poland } & \multirow{2}{*}{0.98} & $K / L$ & 1.17 & 0.13 & 0.000 & $* * *$ \\
\hline & & $Z / L$ & 0.60 & 0.32 & 0.089 & $*$ \\
\hline \multirow{2}{*}{ France } & \multirow{2}{*}{0.92} & $K / L$ & 0.80 & 0.14 & 0.000 & $* * *$ \\
\hline & & $Z / L$ & 0.63 & 0.32 & 0.067 & $*$ \\
\hline \multirow{2}{*}{ Germany } & \multirow{2}{*}{0.93} & $K / L$ & 1.21 & 0.18 & 0.000 & $* * *$ \\
\hline & & $Z / L$ & -2.14 & 1.63 & 0.215 & \\
\hline \multirow{2}{*}{ Great Britain } & \multirow{2}{*}{0.92} & $K / L$ & 1.26 & 0.06 & 0.000 & $* * *$ \\
\hline & & $Z / L$ & -0.37 & 0.10 & 0.002 & $* * *$ \\
\hline \multirow{2}{*}{ Netherlands } & \multirow{2}{*}{0.91} & $K / L$ & 0.844 & 0.10 & 0.000 & $* * *$ \\
\hline & & $Z / L$ & 2.67 & 1.30 & 0.063 & $*$ \\
\hline \multirow{2}{*}{ Lithuania } & \multirow{2}{*}{0.91} & $K / L$ & 0.76 & 0.11 & 0.000 & $* * *$ \\
\hline & & $\mathrm{Z} / \mathrm{L}$ & 0.20 & 0.09 & 0.048 & $* *$ \\
\hline
\end{tabular}

Source: own calculations.

Based on the estimates, it can be assumed that in most of the analyzed countries the technical equipment of this factor, i.e., the $\left(\frac{K}{L}\right)$ ratio, has a greater impact on shaping the level of labor productivity. The $\left(\frac{Z}{L}\right)$ ratio does not have an impact on shaping the labor factor efficiency (in the UK, a negative relationship between these variables has been noticed). The exception is the Netherlands, where the $\left(\frac{Z}{L}\right)$ ratio has a greater impact on shaping the labor productivity than providing the labor factor with the capital factor. These conclusions may be significant for agricultural policy, since according to the results the issue of improving the agrarian structure does not seem to be a priority, whereas the technical equipment of labor seems to be more important. Thus, it is crucial to increase the involvement of the capital factor.

The results of complementary nature (from another study of the author) indicate that the increase in the technical equipment of labor leads to an increase in the productivity of the labor factor, whose relationship depends on the productivity of the capital factor. The higher the productivity of capital, the higher level of technical equipment of labor, which generates higher labor productivity and vice versa.

The second research question is whether technical equipment is shaped more by the loss of the labor factor or more by the increased use of the capital factor. Therefore, the share of the labor and capital factors in shaping the technical equipment of labor was verified. The parameters of the models 10-15 were estimated. 
As indicated in Table 2 (showing the estimated parameters of the 10-15 functions) in all of the analyzed countries (for which the statistically significant parameters were obtained), a much greater negative impact of the labor factor in shaping the level of the technical equipment of labor is noticed. The impact of capital factor is positive.

Table 2

Estimated parameters and errors of regression models describing relation between $K / L$ and the labor and capital factors in the analyzed countries (at a significance level of 0.05)

\begin{tabular}{|c|c|c|c|c|c|c|}
\hline Country & R-squared & $\begin{array}{l}\text { Name of } \\
\text { coefficient }\end{array}$ & $\begin{array}{l}\text { Value of } \\
\text { coefficient }\end{array}$ & $\begin{array}{c}\text { Standard } \\
\text { error }\end{array}$ & p-value & $\begin{array}{l}\text { Statistical } \\
\text { significance }\end{array}$ \\
\hline \multirow{2}{*}{ Poland } & \multirow{2}{*}{0.91} & $\mathrm{~L}$ & -1.62 & 0.29 & 0.000 & $* * *$ \\
\hline & & K & 0.72 & 0.04 & 0.000 & $* * *$ \\
\hline \multirow{2}{*}{ France } & \multirow{2}{*}{0.92} & $\mathrm{~L}$ & -38.10 & 5.45 & 0.000 & $* * *$ \\
\hline & & $\mathrm{K}$ & 1.734 & 0.06 & 0.000 & $* * *$ \\
\hline \multirow{2}{*}{ Germany } & \multirow{2}{*}{0.92} & $\mathrm{~L}$ & -57.66 & 8.15 & 0.000 & $* * *$ \\
\hline & & $\mathrm{K}$ & 2.53 & 0.08 & 0.000 & $* * *$ \\
\hline \multirow{2}{*}{ Netherlands } & \multirow{2}{*}{0.92} & $\mathrm{~L}$ & -231.18 & 22.20 & 0.000 & $* * *$ \\
\hline & & $\mathrm{K}$ & 8.13 & 0.14 & 0.000 & $* * *$ \\
\hline \multirow{2}{*}{ Lithuania } & \multirow{2}{*}{0.92} & $\mathrm{~L}$ & -11.07 & 2.85 & 0.002 & $* * *$ \\
\hline & & $\mathrm{K}$ & 7.41 & 0.18 & 0.000 & $* * *$ \\
\hline
\end{tabular}

Source: own calculations.

The results are consistent with the assumptions and theory. In agriculture, the labor factor decreases and the capital factor involvement increases. The impact of the loss of labor factor on the analyzed technical equipment of labor is greater than the increase in the capital factor's involvement. It should be noticed that this may be related to the microeconomic basis for producer's choice on a given isoquant curve due to changes in the remuneration (prices) of these two production factors (the remuneration of the labor factor increased relative to the remuneration of the capital factor).

The next research question was: which factor - land or labor - shaped the agrarian structure, the $\left(\frac{Z}{L}\right)$ ratio, to a greater extent? Both of these factors, in terms of their involvement in agricultural production are decreasing at various rates. Hence this question. In order to verify the impact of both of these production factors on the analyzed ratio, the parameters of the models (16-21) were estimated.

As indicated in Table 3 (showing estimated parameters of the 16-21 function), in all of the analyzed countries the labor factor (i.e., its de facto loss) has a greater impact on the level of the agrarian structure, which is the approximate $\left(\frac{Z}{L}\right)$ ratio. This is in line with the adopted assumptions. 
Table 3

Estimated parameters and errors of regression models describing relation between $\frac{Z}{L}$ and the labor and land factors in the analyzed countries (at a significance level of 0.1)

\begin{tabular}{|c|c|c|c|c|c|c|}
\hline Country & R-squared & $\begin{array}{l}\text { Name of } \\
\text { coefficient }\end{array}$ & $\begin{array}{l}\text { Value of } \\
\text { coefficient }\end{array}$ & $\begin{array}{c}\text { Standard } \\
\text { error }\end{array}$ & $\mathrm{p}$-value & $\begin{array}{l}\text { Statistical } \\
\text { significance }\end{array}$ \\
\hline \multirow{2}{*}{ Poland } & \multirow{2}{*}{0.91} & $L$ & -4.13 & 0.52 & 0.000 & $* * *$ \\
\hline & & $Z$ & 1.08 & 0.07 & 0.000 & $* * *$ \\
\hline \multirow{2}{*}{ France } & \multirow{2}{*}{0.92} & $L$ & -37.83 & 1.01 & 0.000 & $* * *$ \\
\hline & & $Z$ & 2.35 & 0.03 & 0.000 & $* * *$ \\
\hline \multirow{2}{*}{ Germany } & \multirow{2}{*}{0.92} & $L$ & -70.82 & 2.69 & 0.000 & $* * *$ \\
\hline & & $Z$ & 4.14 & 0.08 & 0.000 & $* * *$ \\
\hline \multirow{2}{*}{ Great Britain } & \multirow{2}{*}{0.91} & $L$ & -45.90 & 14.13 & 0.000 & $* * *$ \\
\hline & & $Z$ & 4.23 & 0.25 & 0.000 & $* * *$ \\
\hline \multirow{2}{*}{ Netherlands } & \multirow{2}{*}{0.91} & $L$ & -83.01 & 43.10 & 0.078 & $*$ \\
\hline & & $Z$ & 13.40 & 3.82 & 0.002 & $* * *$ \\
\hline \multirow{2}{*}{ Lithuania } & \multirow{2}{*}{0.92} & $L$ & -71.07 & 12.79 & 0.000 & $* * *$ \\
\hline & & $Z$ & 10.44 & 0.69 & 0.000 & $* * *$ \\
\hline
\end{tabular}

Source: own calculations.

According to the theory of agricultural economics and empirical observations, changes in the involvement of the land factor and labor factor are not steady, because the rate of outflow of the labor factor is faster than the rate of decline of the land factor used in agriculture. Thus, the impact of the labor factor on the agrarian structure, which is more significant, results from the relatively higher degree of scarcity of the labor factor relative to the land factor.

This leads to an increase in the value of the coefficient illustrating structural changes (relation between the land factor and the labor factor), and in particular the degree of concentration, which can be seen on the surface of phenomena as an agrarian structure. ${ }^{3}$ The increase of this coefficient creates the basis for improving the productivity of the labor factor, and therefore also the agricultural income, with the condition of increasing the productivity of the land factor. It can be assumed, however, that this process is not dynamic enough, because the $\left(\frac{Z}{L}\right)$ relationship should increase more, especially since it is an important source of labor productivity growth, and thus of agricultural income (certainly apart from support). Thus, reducing employment in the labor factor in agriculture should be accompanied by an increase in its productivity and its remuneration (prices). This, in turn, leads, and above all, results from changes in manufacturing techniques towards labor-

\footnotetext{
${ }^{3}$ Land consolidation is a long-term measure for increasing agricultural production efficiency. In Poland, Slovenia, and Lithuania, land consolidation was mainly introduced as an instrument to address the structural problems in agriculture arising from fragmentation of both land ownership and land use as a tool to improve productivity and competitiveness of small and medium farms.
} 
saving techniques. This is in close relation to the degree of rarity of this factor, which is reflected in its price (remuneration) and productivity. These processes can be analyzed based on the observations of the surface of phenomena, ie., structural changes in agriculture in this context.

\section{Conclusions}

All changes in factor relations are mutually conditioned and illustrate or even define changes in production techniques in agriculture. As a rule, in terms of production factors in agriculture, the importance of the capital factor in shaping the production volume is higher than the labor and the land factors. That is in line with current agricultural trends involving the transition from labor-intensive and land-intensive techniques to capital-intensive as well as labor- and land-saving techniques.

The research presented in the paper allowed the author not only to deeply recognize the correctness of production techniques, but also determine the relations among production factors. The research on relations between production factors is very complex, thus the paper focuses only on some areas of the problem, such as: labor productivity and its dependency on technical equipment of labor or agrarian structure (approximate land-labor ratio) and the dependency of the capital-labor and land-labor ratios on production factors.

Based on the theoretical assumptions and empirical results, it was concluded that the technical equipment of labor, i.e., the $\left(\frac{K}{L}\right)$ ratio, has a greater impact on the level of labor productivity. The $\left(\frac{Z}{L}\right)$ ratio does not have an impact on shaping the labor factor efficiency. These conclusions may be significant for agricultural policy, since improving the agrarian structure does not seem to be a priority, whereas the technical equipment of labor seems to be more important. Thus, it is crucial to increase theinvolvement of the capital factor.

The impact of the loss in the labor factor on the technical equipment of labor is greater than the increase in the capital factor involvement. This may be related to the microeconomic basis for producer's choice on a given isoquant curve due to changes in the remuneration (prices) of these two production factors (the remuneration of the labor factor increased relative to the remuneration of the capital factor).

The greater impact of the labor factor results from the relatively higher degree of scarcity of the labor factor relative to the land factor. It can be assumed, however, that this process is not dynamic enough, because the $\left(\frac{Z}{L}\right)$ ratio should increase more, especially since it is an important source of labor productivity growth, and thus agricultural income (apart from external financial support).

According to the theory of agricultural economics and empirical observations, changes in the involvement of the land and labor factors are not even, because the rate of outflow of the labor factor is faster than the rate of decline of the land factor used in agriculture. Thus, the greater impact of the labor factor on the agrarian structure results from the relatively increasing degree of scarcity of the labor factor relative to the land factor. 


\section{Acknowledgements}

Research financed within the scholarship conducted in Australia in 2013 (School of Economics, the University of Queensland, Brisbane) and by the Ministry of Agriculture and Rural Development, Multi-Annual Program 2015-2019. 


\section{References}

Aigner, D.J., Chu, S.F. (1968). On Estimating the Industry Production Function. American Economic Review, 58, pp. 826-839.

Bezat-Jarzębowska, A., Rembisz, W. (2018). Mikroekonomia relacji czynników produkcji w rolnictwie. Warszawa: Vizja Press\&IT.

Clark, J.B. (1915). Essentials of Economic Theory. New York: The Macmillan Company.

Fried, H.O., Lovell, C.A,K., Schmidt, S.S. (2008). The Measurement of Productive Efficiency and Productivity Growth. New York: Oxford University Press.

Harlemann, H., Stamer, H. (1963). Rolnictwo w dobie technizacji. Warszawa: PWRiL.

Hayami, Y., Ruttan, V. (1970). Factor Prices and Technical Change in Agricultural Development: the United States and Japan. Journal of Political Economy, 78(5), pp. 1115-1141.

Hayami, Y., Ruttan, V. (1985). Agricultural Development: An International Development, rev. expanded edition. Baltimore: Johns Hopkins University Press.

Heady, E.O., Dillon, J.L. (1961). Agricultural Production Functions. Ames: Iowa State University Press.

Jorgenson, D.W. (1961). The Development of a Dual Economy. The Economic Journal, 71(282), pp. 309-334.

Murphy, K.M., Shleifer, A., Vishny, R. (1989). Income Distribution, Market Size, and Industrialization. The Quarterly Journal of Economics, 104, pp. 537-564.

Ranis, G., Fei, J.C.H. (1961). A Theory of Economic Development. American Economic Review, 51, pp. 533-565.

Rembisz, W., Waszkowski, A. (2017). Exogenous Determinants of Agricultural Production Prices of the Production Factors and the Selected Macroeconomic Indicators. Monographs of Multi-Annual Programme, No. 69.1. Warszawa: IAFE-NRI.

Shepard, R.W. (1953). Cost and Production Functions. Princeton: Princeton University Press.

Shepard, R.W. (1970). Theory of Cost and Production Functions. Princeton: Princeton University Press.

Woś, A., Tomczak, F. (1983). Ekonomika rolnictwa. Zarys teorii. Warszawa: PWRiL. 


\title{
RELACJE CZYNNIKOWE W ROLNICTWIE - ZARYS KONCEPCJI WRAZ Z WERYFIKACJĄ EMPIRYCZNA
}

\begin{abstract}
Abstrakt
Przedstawione $w$ artykule badanie pozwolito autorowi nie tylko $w$ petni ocenić prawidłowość procesów produkcyjnych, ale również określić relacje między czynnikami produkcji a wielkościa produkcji (produktywność i relacje czynnikowe). Opierając się na przyjętych założeniach analitycznych i ogólnych uwarunkowaniach procesów gospodarowania $w$ rolnictwie, $w$ artykule przeanalizowano relacje między czynnikami produkcji, tj. istote technik produkcji. Badania relacji między czynnikami produkcji sa bardzo złożone, dlatego w artykule skupiono się tylko na wybranych obszarach tej problematyki, takich jak: efektywność pracy i jej zależność od technicznego uzbrojenia pracy czy struktury agrarnej (przybliżony wskaźnik ziemia-praca) oraz zależność wskaźników kapitat-praca i ziemia-praca od czynników produkcji. Analiza została oparta na zasadzie ogólności, $a w$ artykule zastosowano metodologiczne podejście do dedukcji. W części empirycznej wykorzystano zbiór danych dla wybranych krajów UE. Stwierdzono, że w porównaniu ze wskaźnikiem $\left(\frac{Z}{L}\right)$ wskaźnik $\left(\frac{K}{L}\right)$ ma większy wptyw na poziom efektywności pracy. Wnioski te moga mieć istotne znaczenie dla polityki rolnej, gdyż priorytetem nie wydaje się być poprawa struktury agrarnej, lecz techniczne uzbrojenie pracy. Dlatego tak istotne jest zwiększenie zaangażowania zasobów czynnika kapitatu.
\end{abstract}

Słowa kluczowe: relacje czynnikowe, produktywność rolnictwa, czynniki produkcji.

Accepted for print: 16.03.2021.

Unless stated otherwise all the materials on the website are available under the Creative Commons Attribution 4.0 International license.

Some rights reserved to the Institute of Agricultural and Food Economics - National Research Institute.

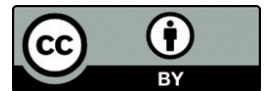

